RECYT

Year 23 / № 36 / 2021 / 24-29

\title{
Evaluation of resources in the study of industrial and culinary properties for the varietal characterization of rice (Oryza sativa L.)
}

\section{Evaluación de recursos en el estudio de las propiedades industriales y culinarias para la caracterización varietal de arroz (Oryza sativa L.)}

\author{
Andrea P. Farcoํㅜ, José D. Bouchard¹, Sergio F. Díaz, Raúl D. Kruger², Marcos G. Maiocchi \\ 1- Facultad de Ciencias Exactas y Naturales y Agrimensura. Universidad Nacional del Nordeste. Av. Libertad 5450. \\ 2- Instituto Nacional de Tecnología Agropecuaria, Estación Experimental Corrientes. \\ ^E-mail: marcos.maiocchi@comunidad.unne.edu.ar
}

\section{Abstract}

Different physicochemical tests have been used over time in the Oryza sativa species for the study of industrial and culinary properties. In this study, nine attributes were compared: amylose content, total whiteness, thousand grain weight, grain length and width, gelatinization time, apparent water absorption, expansion ratio, and gelatinization temperature. However, there is no single attribute that allows defining the concept of "culinary quality" in rice, since it depends on its behavior after cooking. The two varieties of long fine polished rice used for this study were: IRGA 424 (Rio Grandense Rice Institute) and Tranquilo FL INTA (National Institute of Agricultural Technology) and a mixture of both.

In this work, the characterization of industrial and culinary properties of the rice varieties mentioned above was achieved by evaluating five attributes using simple and low-cost physical-chemical techniques in two of the rice varieties most in demand by producers in the province of Corrientes. This finding would allow the study of rice varieties to be approached by optimizing: equipment, reagents and time in future trials.

Keywords: rice; optimization; culinary quality.

\section{Resumen}

Distintas pruebas físico químicas se han utilizado a lo largo del tiempo en la especie Oryza sativa para el estudio de las propiedades industriales y culinarias. En este estudio, se compararon nueve atributos: contenido de amilosa, blancura total, peso de mil granos, largo y ancho de los granos, tiempo de gelatinización, absorción aparente de agua, relación de expansión y temperatura de gelatinización. Sin embargo, no existe un único atributo que permita definir el concepto de "calidad culinaria" en arroz, ya que éste depende de su comportamiento luego de la cocción. Las dos variedades de arroz largo fino pulido utilizadas para este estudio fueron: IRGA 424 y Tranquilo FL INTA y además los granos de un cultivar producto de la mezcla 50/50 de las semillas de ambas variedades.

En este trabajo, se logró la caracterización de propiedades industriales y culinarias de las variedades de arroz citadas precedentemente mediante la evaluación de cinco atributos utilizando técnicas físico químicas simples y de bajo costo en dos de las variedades de arroz de mayor demanda por parte de los productores de la provincia de Corrientes. Este hallazgo, permitiría abordar el estudio de variedades de arroz optimizando: equipamiento, reactivos y tiempo en futuros ensayos.

Palabras clave: arroz; optimización; calidad culinaria.

\section{Introduction}

Rice characteristics depend not only on the variety, but also on other factors such as growing, drying or storage conditions [1]. Moreover, consumer preference for a certain type of rice varies widely from one part of the world to another. Besides, within the same area, the preference for a given variety depends on the type of dish to be prepared. This situation makes it necessary: a) to know the type of rice suitable for each specific use, either in direct consumption or in industrialisation; $b$ ) to know the characteristics of each consignment in order to supply the consumer with the rice he needs [2]. Rice grain quality can be assessed from milling (or industrial) and culinary quality attributes [3], 
[4]. The industrial quality is evaluated using as a parameter the percentage of whole grains with respect to paddy rice. Culinary quality, on the other hand, is identified with the expected behaviour of rice after cooking, represented by a set of characteristics related to the chemical structure of starch [5]; which is a macromolecule composed of polymers of glucose, amylose and amylopectin [6]. Therefore, the higher or lower amylose content in the grain determines the quality of cooked rice in terms of cohesiveness, expansion volume, texture and gloss [7].

The physical properties of rice, such as hardness, water absorption, cohesiveness (among others), are associated with cooking and are more closely related to the gelatinisation temperature (GT) and amylose content [8]. Thus, GT is defined as the temperature at which the starch in the endosperm irreversibly loses its crystalline structure, with a reduction in the mechanical strength of the grain constituting the hardness [9]. On the other hand, the gelatinisation time is defined as the time required for $90 \%$ of the grains to change from their natural state to gel (ISO 14864) (International Organization for Standardization) [10]. It correlates with the starch hydration process when rice is cooked in water at high temperature. This process, first slowly and then rapidly, induces an irreversible change in the physical structure of starch. Its crystalline granules become colloidal, losing the characteristic of crystallinity [11]. Continuing with the relationship between rice grain properties and quality, physicochemical properties include: size, shape, weight, pigmentation, hardness, TG, amylose content, etc. [12]. All these parameters are part of the indirect assessment of the culinary quality of rice [13].

Meanwhile, attributes such as water absorption and the loss of solids along with expansion volume, are linked to the degree of maturity of the grain and to the drying and storage conditions [14], [15]. Consequently, the expansion volume is a measure of the decrease in cohesiveness (or stickiness) of the rice [16]. However, regardless of the market, the texture of cooked rice represents one of the main quality attributes for rice [17]. In this sense, routine tests carried out in laboratories are oriented to look for relationships between the optimal cooking time and the physicochemical properties of the grain [18].

In Corrientes (Argentina), the IRGA 424 rice variety is in great demand because it is characterised by a high agronomic yield [19]. On the other hand, in 2011 the "INTA Rice Project" registered the first variety of FLAR (Latin American Fund for Irrigated Rice) origin for the Southern Cone of Latin America: Tranquilo FL-INTA. This variety has good grain quality characteristics such as: $0.2 \%$ white belly, high amylose content (a culinary characteristic demanded by the region's markets) and tolerance to crop delay [20]. Both varieties are sown and highly accepted by producers in the area, with behaviours that differ year after year as a result of agro-ecological variations, farm size and form of land tenure. [21].
Due to these changes in the behaviour of the varieties, which are not predictable in most cases, technicians at the INTA Corrientes Agricultural Experimental Station recommend producers to sow more than one variety (using mixtures of cultivars), in order to have greater heterogeneity and security at the end of the season [22]. Mixing rice varieties in different proportions would be an interesting tool to increase yield stability in the field, maintain rice quality and reduce phytosanitary problems in the province of Corrientes.

The aim of this work was to save the required resources that demand the study of the main industrial and culinary properties of polished long rice (IRGA 424 and Tranquilo FL INTA varieties and a sample from a 50/50 sowing of both varieties) using simple techniques and reducing the environmental impact.

\section{Materials and methods}

Samples: processed rice (polished) was worked with according to the following denomination: IRGA 424 and Tranquilo FL INTA, apart from the material obtained by sowing a 50/50 mixture of the aforementioned varieties. Samples of $5 \mathrm{~kg}$ for each treatment, harvested, dried and ground were provided by the Seed and Grain Quality Laboratory from INTA EEA Corrientes, during the 2017-2018 season. The grains were dried in a pilot dryer at $50{ }^{\circ} \mathrm{C}$ (Metalúrgica Reynaldo Ventura, 24/10, Argentina), kept at $12 \%$ humidity level and stored in airtight plastic containers at ambient temperature until their study. Three samples of the two varieties and their mixture were received. The tests were carried out in triplicate using the following techniques.

\section{Industrial properties}

Weight of one thousand grains: The weight of one thousand whole grains of rice was recorded [23].

Grain appearance: The Suzuki S-21 Statistical Rice Analyser (LKL Tecnologia da Informação Ltda, Brazil, 2013) was used to determine the length ( $\mathrm{mm})$, width (mm) and length/width ratio. Whiteness was measured with a Kett C-300 bleachmeter (Kett Electric Laboratory, Japan, 2011).

\section{Culinary properties}

Amylose content: The simplified method of Juliano (1971) [24] was used. Samples of 30 to $50 \mathrm{~g}$ of polished whole rice were taken, cleaned with a dry linen cloth and ground. Of the flour obtained, $100 \mathrm{mgs}$ were placed in a $100 \mathrm{~mL}$ Erlenmeyer flask and $1 \mathrm{~mL}$ of $96 \%$ ethanol together with $9 \mathrm{~mL}$ of $1 \mathrm{~N} \mathrm{NaOH}$ were added. The starch was gelatinised in a water bath for 10 minutes. The contents were transferred by washings into a $100 \mathrm{~mL}$ flask, 
brought to volume with distilled water and shaken. 5 $\mathrm{mL}$ of the starch solution was placed in $100 \mathrm{~mL}$ flasks, with the addition of $1 \mathrm{~mL}$ of $1 \mathrm{~N}$ acetic acid and $2 \mathrm{~mL}$ of $0.2 \%$ iodine solution. It was brought to volume with distilled water, shaken and left to stand for 30 minutes. The absorbance was measured in an EXILON 752 UV-Visible spectrophotometer at $720 \mathrm{~nm}$. The amylose content was calculated on the basis of standard curves constructed with pure potato amylose (Sigma) at $720 \mathrm{~nm}$.

Gelatinisation time: The method of Ranghino ISO 14864:2004 [25] was used. $100 \mathrm{~mL}$ of distilled water was placed in a $250 \mathrm{~mL}$ beaker and brought to a boil over a hot plate (Velp Científica, Are 2, Argentina). When boiling started, 5 grams of sample were added. After 12 minutes, 10 grains of rice were removed with the help of a perforated spoon to drain the excess water, then pressed between two glass plates, a procedure that was repeated at 1 min intervals, until $90 \%$ of the grains analysed showed a translucent centre.

Water absorption: test tubes containing $20 \mathrm{~mL}$ of distilled water were placed in a $100{ }^{\circ} \mathrm{C}$ bath (Tecnodalvo, TDA/I/6, Argentina). Once the temperature was equilibrated, 2,00 grams of rice were added to the tubes, stirred with the aid of a tempered glass rod and left to cook without stirring for 20 minutes. The resulting cooked rice was transferred to a Whatman No. 5 paper filter and spread out using a glass rod. The excess water was removed by gently pressing on the sample with another filter paper. The grains were then placed in a pre-weighed Petri dish. The apparent water absorption was calculated by difference between weighings [26].

Volume expansion: This was carried out according to the methodology proposed by Desikachar (1965) [27]. $20.00 \mathrm{~g}$ of milled rice were placed in $100 \mathrm{~mL}$ test tubes. Then $50 \mathrm{~mL}$ of distilled water was added to each, covered with cotton wool and an aluminium foil cover. The test tubes were autoclaved at $100{ }^{\circ} \mathrm{C}$ for $45 \mathrm{~min}$ (Arcano, LSB75L, China). After this time the test tubes were removed from the autoclave and the volume achieved by the cooked rice bed was measured in each tube. The results were expressed as the ratio between the final and initial volume.

Gelatinisation temperature: this was indirectly estimated from the degree of alkali spreading value (ASV) based on the "alkali test", a method developed by Little et al (1958) [28] for which 10 whole grains of polished rice were evenly distributed in 6 well CorningTM capsules and then $10 \mathrm{~mL}$ of a $1.7 \% \mathrm{KOH}$ solution (Biopack) was added and incubated at $30{ }^{\circ} \mathrm{C}$ for $23 \mathrm{~h}$ (Mariotti, Fongaro, $\&$ Catenacci, 2010) [29]. The degree of dispersion is obtained by comparing individual grains with a scale of standard images and calculating the weighted average. The correspondence between ASV (Alkaline Dispersion) and TG (Gelatinisation temperature) was evaluated according to table 1 [30].
Table 1: Correspondence between ASV and TG categories.

\begin{tabular}{|c|c|}
\hline Alkaline Dispersion (ASV) & Gelatinisation temperature $(\mathrm{TG})\left({ }^{\circ} \mathrm{C}\right)$ \\
\hline $1-3$ & High $74-80$ \\
\hline $4-5$ & Intermediate $69-73$ \\
\hline $6-7$ & Low $63-68$ \\
\hline
\end{tabular}

The data analysis was carried out with the Correlation Matrix; besides, the multivariate statistical technique of Hierarchical Cluster Analysis and the Non-Parametric Analysis of Variance (PERMANOVA) were used to analyse the joint behaviour of the variables, using $\mathrm{R}$ software (IDE RStudio 1.2.1335).

\section{Results and discussion}

Table 2 shows the results obtained in the determinations of total whiteness, length, width, amylose, gelatinisation time, absorption, expansion volume, thousand-grain weight and alkaline dispersion in polished rice samples of the varieties Tranquilo FL INTA, IRGA 424 and the 50/50 mix.

Table 2: Total whiteness, length, width, amylose, gelatinisation time absorption, expansion volume, thousand-grain weight and alkaline dispersion in polished rice samples of the varieties Tranquilo FL INTA, IRGA 424 and the 50/50 blend.

\begin{tabular}{|l|c|c|c|}
\hline \multicolumn{1}{|c|}{ Sample/ Trial } & Tranquilo FL INTA & IRGA 424 & Mixture 50/50 \\
\hline Total whiteness & $123,02 \pm 6,20$ & $135,86 \pm 2,93$ & $137,85 \pm 0,50$ \\
\hline Length (mm) & $6,49 \pm 0,13$ & $6,45 \pm 0,03$ & $6,51 \pm 0,03$ \\
\hline Width (mm) & $1,75 \pm 0,03$ & $1,83 \pm 0,03$ & $1,80 \pm 0,02$ \\
\hline Amylose (\%) & $17,09 \pm 0,10$ & $26,16 \pm 0,20$ & $23,19 \pm 0,56$ \\
\hline Gel time (min) & $17,0 \pm 0,6$ & $16,9 \pm 0,2$ & $16,7 \pm 0,3$ \\
\hline Absorption (g/g) & $2,19 \pm 0,01$ & $2,43 \pm 0,06$ & $2,43 \pm 0,07$ \\
\hline Vol. exp.(mL/mL) & $2,77 \pm 0,02$ & $3,18 \pm 0,01$ & $2,99 \pm 0,05$ \\
\hline $\begin{array}{l}\text { Weight per thousand } \\
\text { grains (g) }\end{array}$ & $17,54 \pm 0,68$ & $18,46 \pm 0,21$ & $18,11 \pm 0,04$ \\
\hline Alkaline Dispersion (ASV) & $4,60 \pm 0,00$ & $5,53 \pm 0,46$ & $5,23 \pm 0,12$ \\
\hline
\end{tabular}

The values correspond to the average of three determinations \pm the standard deviation.

Figure 1 shows the double-entry correlation matrix with the 9 variables linked to each other, which allows the simultaneous visualisation of the behaviour of all the variables in terms of the sign of the correlation and its fit. 


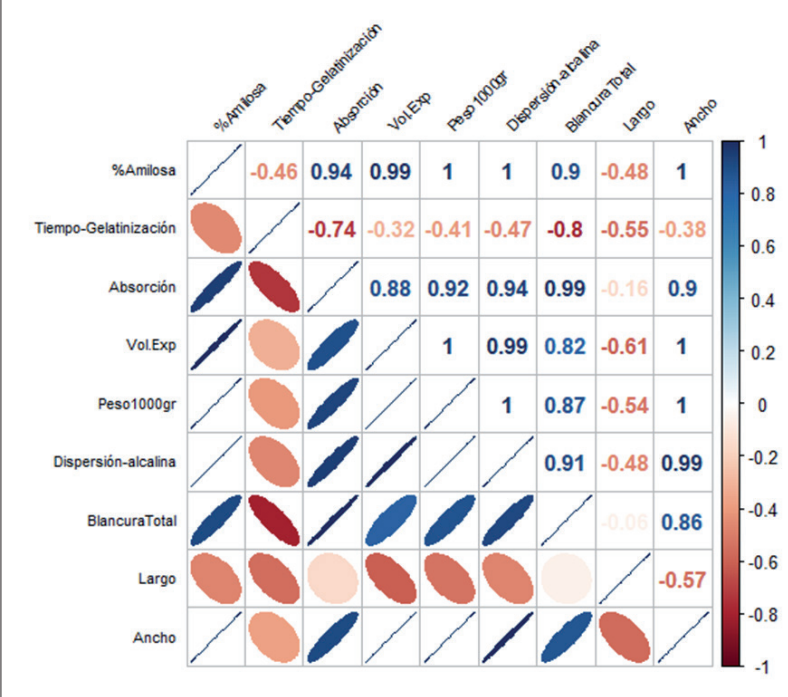

Figure 1: Correlation matrix of the 9 variables in polished rice samples of the varieties Tranquilo FL INTA, IRGA 424 and the 50/50 mixture.

In a first analysis, it can be observed that most of the variables have acceptable correlations with each other.

The exceptions are length and gelatinisation time, which have very good correlations with each other, but very low correlations with the others, in the case of length almost nil with total whiteness, amylose, alkali dispersion, width, expansion volume and absorption. And in some cases they are negative correlations.

It is observed that the longer the kernel, the longer the gelatinisation time and the higher the weight of 1000 kernels. In the case of width, there is no relationship, i.e. the width and length of the kernel are independent.

While the gelatinisation time attribute has a low relationship with the variables, except for length, and practically no correlation with width and expansion volume.

For comparisons, cluster dendrograms were used. In the first stage, nine quality attributes were included in the statistical analysis, as follows: amylose content, total whiteness, thousand kernel weight, kernel length and width, gelatinisation time, apparent water absorption, expansion ratio and gelatinisation temperature (figure 2 ). In the second stage, seven attributes were included in the analysis, without considering in this case the studies of gelatinisation temperature and amylose, with the aim of verifying whether it was possible to discriminate the behaviour between samples with a reduction in analysis time and savings in reagents (figure 3). Finally, in a third stage, only five attributes were analysed, which require less equipment: thousand-grain weight, gelatinisation time, apparent water absorption, expansion volume and gelatinisation temperature (figure 4).

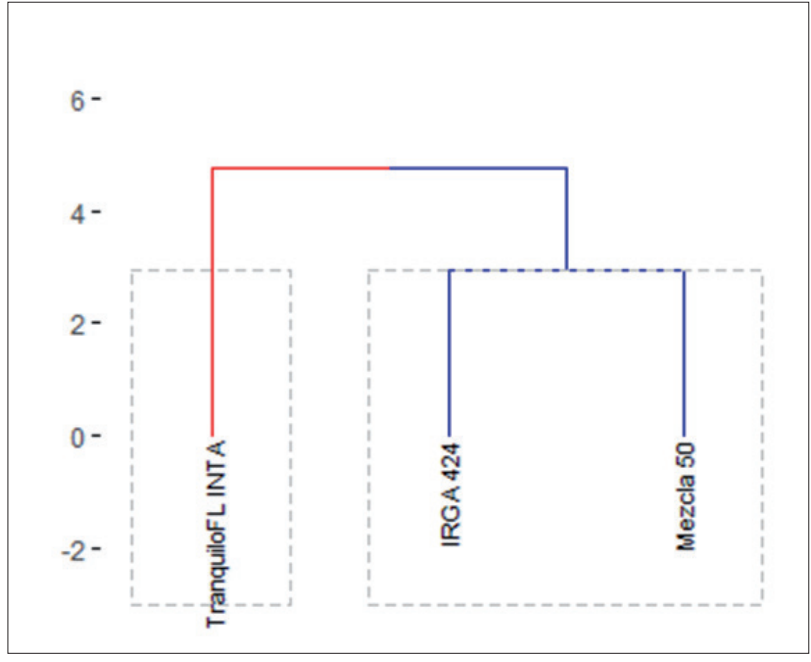

Figure 2: Cluster dendrogram of the nine attributes studied: amylose content, total whiteness, thousand kernel weight, kernel length and width, gelatinisation time, apparent water absorption, expansion ratio and gelatinisation temperature in polished rice samples of the varieties Tranquilo FL INTA, IRGA 424 and the 50/50 blend.

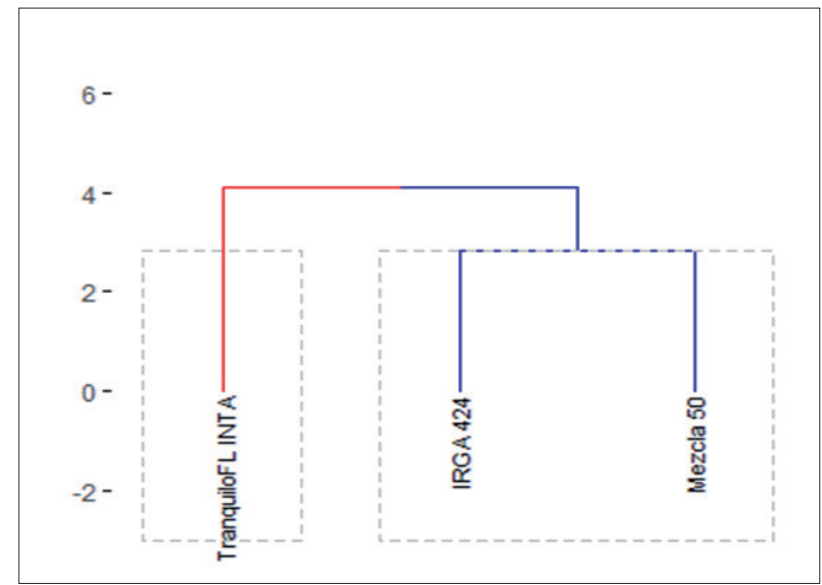

Figure 3: Cluster dendrogram of the seven attributes studied: total whiteness, thousand kernel weight, kernel length and width, gelatinisation time, apparent water absorption and expansion ratio in polished rice samples of the varieties Tranquilo FL INTA, IRGA 424 and the 50/50 blend.

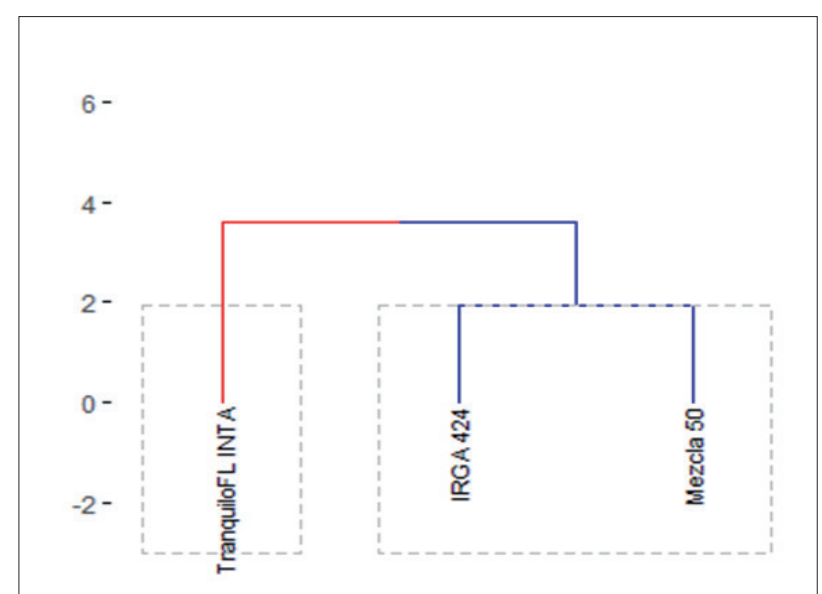

Figure 4: Cluster dendrogram of the five attributes studied: thousandgrain weight, gelatinisation time, apparent water absorption, expansion ratio and gelatinisation temperature in polished rice samples of the varieties Tranquilo FL INTA, IRGA 424 and the 50/50 mixture. 
These dendrograms showed co-phenetic correlation coefficients of $0.91,0.93$ and 0.96 respectively. It was observed that they were constituted in such a way that the $50 / 50$ mixture sample is more similar to IRGA 424 than to the variety Tranquilo FL INTA, analysing all the variables simultaneously.

PERMANOVA was applied to analyse if there are differences between the variables in the different treatments $\left(\mathrm{F}=32.206, \mathrm{p}=0.005^{* * *}\right)$ and as a result, statistically significant differences were observed between the variables.

To identify the variables with differences, non-parametric ANOVA (Kruskal-Wallis test) was used for each of them.

Table 3: Kruskal-Wallis test for the 9 variables for rice samples of variety Tranquilo FL INTA, IRGA 424 and the 50/50 mixture.

\begin{tabular}{|l|c|c|}
\hline \multicolumn{1}{|c|}{ VARIABLE } & STATISTICAL "H" & "p" VALUE \\
\hline Amylose \% & 7,20 & 0,0036 * \\
\hline Time-Gelatinisation & 0,96 & 0,7179 \\
\hline Absortion & 5,42 & 0,0607 \\
\hline Expansion Volume & 7,20 & 0,0036 * \\
\hline Weight 1000 grains & 5,60 & 0,0500 \\
\hline Alkaline Dispersion (ASV) & 5,60 & 0,0214 \\
\hline Total whiteness & 5,60 & 0,0500 \\
\hline Length & 2,42 & 0,3369 \\
\hline Width & 5,07 & 0,0785 \\
\hline \multicolumn{2}{|c|}{ *Variables showing statistically significant differences. } \\
\hline
\end{tabular}

Comparing the results obtained from the present work with those of other authors, González et al [31] reported significantly lower cooking time values for IRGA varieties than those obtained in this work (12.5 min vs. $16.9 \pm$ 0.2 average for IRGA 424 varieties). The same authors reported a water retention value for IRGA of $2.8 \mathrm{~g} / \mathrm{g}$ (vs. $2.43 \pm 0.06)$.

Bouchard et al. [32] report for the varieties IRGA 424 and Tranquilo results for gelatinisation time, absorption and alkaline dispersion without significant differences with respect to those obtained in this work. Whereas, for the attributes, expansion volume and thousand kernel weight, the differences are around 5\%.

\section{Conclusions}

Multiple coincidences with data published by other authors are observed and it has contributed to the knowledge of the behaviour of varieties whose seed mixture has not been studied in these aspects so far. It is possible to affirm, in the cases analysed and under the conditions established in this work, that the 50/50 mixture sample has attributes similar to those of the IRGA 424 variety, given its higher yield, it has a higher final field share than the Tranquilo FL INTA variety, and higher field yields are obtained with mixtures of varieties with a higher percentage of IRGA 424.

Comparing 5 attributes (thousand kernel weight, gelatinisation time, apparent water absorption, expansion ratio and gelatinisation temperature), 7 (thousand kernel weight, gelatinisation time, apparent water absorption, expansion ratio, whiteness, kernel length and width), 9 (thousand kernel weight, gelatinisation time, apparent water absorption, expansion ratio, whiteness, length and width of the kernel), and 9 (thousand kernel weight, gelatinisation time, apparent water absorption, expansion ratio, whiteness, length and width of the kernel), gelatinisation time, apparent water absorption, expansion ratio, whiteness, kernel length and width, amylose and gelatinisation temperature); it was observed that the dendrograms did not change, i.e. the conformation of these three groups remained similar in the different cases studied. This allows us to recommend that, in situations where time, reagents or equipment are scarce, it is possible to make progress in the analysis of industrial and culinary quality, using simple and economical methods.

\section{References}

1. Primo, E.; Barber S. (1970). Agroquímica y tecnología de alimentos. Vol.10. p.393-405.

2. Juliano, B. O. (1985). Criteria and tests for rice grain qualities. In: Juliano, B. O. (Ed.). Rice: chemistry and technology. 2. ed. Saint Paul: American Association Cereal Chemistry, p. 443-524.

3. León, J. L.; Carreres, R. (2002). Calidad del Arroz: Criterios para una adecuada valoración. Vida Rural. p. 38-40.

4. Martínez, C.; Cuevas, F. (1989). Evaluación de la calidad culinaria y molinera del arroz. Cali, Colombia: Centro Internacional de Agricultura Tropical.

5. Kusano,M.; Fukushima, A.; Fujita, N.; Kobayashi, M.; Oitomen, F.; Ebana, K. (2012) Deciphering Starch Quality of Rice Kernels Using Metabolite Profiling and Pedigree Network Analysis. Molecular Plant. Vol. 5. n 2 2. p. 442 - 451.

6. Juliano, B. (2007). Nutritive Value of Rice and Rice Diets. Manila, Philippine: Rice Chemistry and Quality.

7. Jennings, P. R.; Coffman, W. R.; Kauffman, H. E. (1979). In Rice Improvement. Los Baños, Philippines: International Rice Research Institute.

8. Cuevas, R.; Daygon, V.; Corpuz, H.; Leilani, N.; Reinke, R.; Waters, D.; Fitzgerald, M. (2010).Melting the secrets of gelatinization temperatura un rice. Functional Plant Biology. Vol.37. p. 439-447.

9. Khush, G. S.; Paule, C. M.; De la Cruz, N. M. (1979). Rice grain quality evaluation and improvement at IRRI. In IRRI, Proceedings of the Workshop on Chemical Aspects of Rice Grain Quality. Los Baños, Laguna, Philippines.

10. Iso -International Organization for Standardization. (1998). Norma ISO 14864. Evaluation of gelatinization time of kernels during cooking.

11. Tinarelli A. (1999) "Appunti di Merceologia - Il Riso nelle sue caratteristiche e Qualità". Ed. Saviolo.

12. Bhattacharya, K. R. (2011). In K. R. Bhattacharya, Rice quality: A guide to rice properties and analysis. p. 26-60. 
Cambridge, U.K.: Woodhead Publishing.

13. He, M.; Qiu, C.; Liao, z.; Sui, Z.; Corke, H. (2018). Impact of cooking conditions on the properties of rice: Combined temperature and cooking time. International Journal of Biological Macromolecules, vol.117, p. 87-94.

14. Daniels, M.; Marks, B.; Siebenmorgen, T.; McKnew, R.; Meullenet, J. (1998) Efectos del historial de almacenamiento del arroz en bruto de grano largo sobre la calidad del uso final. J Food Sci. Vol.63. p. 832-835.

15. Villareal, R.; Resurreccion, A.; Suzuki, L.; Juliano, B. (1976). Changes in Physicochemical Properties of Rice during Storage. Starch, Vol. 28. n³. p. 88-94.

16. Tsugita, T.; Ohta, T.; Kato, H. (1983). Cooking Flavor and Texture of Rice Stored under Different Conditions. Agricultural and Biological Chemistry. Vol. 47. n³. p. 543-549.

17. Syafutri, M.; Pratama, F.; Syaiful, F.; Faizal, A. (2016). Effects of Varieties and Cooking Methods on Physical and Chemical Characteristics of Cooked Rice. Rice Science. Vol. 23. n5. p.282-286.

18. Vidal, V.; Pons, B.; Brunnschweiler, J.; Handschin, S.; Rouau, X.; Mestres, C. (2007). Cooking behavior of rice in relation to kernel physicochemical and structural properties, $J$. Agricultural Food Chemistry. Vol.55. n 2 2. p. 336-346.

19. Pachecoy, M.; Maciel, S.; Cattaneo, F.; Casco, J.; Ayala, J.; Vicino, R.; Opstal, J. S. (2019). Ensayos regionales de cultivares. Proyecto arroz. Resultados Campaña 2018/2019. p. $1-11$.

20. [20] Instituto Nacional de Tecnología Agropecuaria INTA, 2011. https:/intainforma.inta.gob.ar/llego-tranquilo-fl-intael-arroz-del-cono-sur/ Ingreso Octubre 2020.

21. Cortazar S. R. (1987). Factibilidad del uso de mezclas de variedades de trigo, en la zona centronorte de Chile. Agricultura Técnica (Chile). Vol. 47. n². p. 108 - 112.

22. Blanco, D.N.; Kruger, R.D. (2017). Mezcla de variedades de arroz de ciclo intermedio: alternativa para incrementar rendimiento y calidad - Campaña 2015/16. Resultados campaña 2016/17. Vol. XXV. p. 101-110. ISSN 0327-4209.

23. M. Puig. "Tesis de grado: Ambiente y Calidad de grano en genotipos de arroz (Oryza sativa) tipo comercial largo ancho", Facultad de Ciencias Agrarias y Forestales. Universidad Nacional de La Plata, La Plata, 2016.

24. Juliano, B.o. (1971). A simplified assay for milled rice amylose. Cereal Science Today. Vol.16. p.334-338.

25. Simonelli, C.; Cormegna, M.; Galassi, L.; Bianchi, P. (2013). Cooking time and gelatinization time of rice Italian varieties. La Revista di Scienza dell'Alimentazione. Vol. 42. $n^{\circ}$ 2. p. 37-43.

26. Bouchard, J.; Maciel, S.; Maiocchi, M.; Marin, A. (2016). Estudio comparativo de la calidad industrial y culinaria de arroz (Oryza sativa) variedades Fortuna INTA y Yerua. FaCENA. Vol.32. p. 27-33.

27. (Desikachar H.; Raghavendra Rao, S.; Ananthachar, T. (1965). Effect of degree of milling on water absorption of rice during cooking. Journal of Food Science and Technology. Vol. 2. p. 110-112.

28. Little, R.; Hilder, G.; Dawson, E. (1958). Differential effect of dilute alkali on 25 varieties of milled hite rice. Cereal Chemistry. Vol. 35.

29. Mariotti, M.; Fongaro, L.; Catenacci, F. (2010). Alkali Spreading Value and Image Analysis. Journal of Cereal Science. Vol.1. $n^{\circ}$ 52. p. 227-235.

30. Martínez, C.; Cuevas, F. (1989). Evaluación de la calidad culinaria y molinera del arroz. Cali, Colombia.: Centro Internacional de Agricultura Tropical.

31. González, R.; Livore, A.; Pons B. (2004). Physico-Chemical and Cooking Characteristics of Some Rice Varieties. Brazilian Archives of Biology and Technology. Vol. 47. $n^{\circ} 1$. p. 71-75.

32. Bouchard, J. D., Acevedo, B. A., Díaz, S. F., \& Maiocchi, M. G. (2020). Análisis multivariante aplicado al estudio de las propiedades culinarias de arroz (Oryza sativa L.) en variedades largo fino. Revista de Ciencia y Tecnología. Vol.33. $n^{\circ} 1$. p. 33-37. 